WORLD RESOURCES AND PEACE 



\section{WORLD RESOURCES AND PEACE}

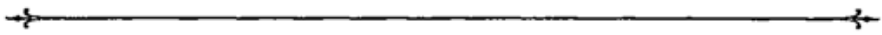

LECTURES DELIVERED UNDER THE AUSPICES OF THE COMMITTEE ON INTERNATIONAL RELATIONS

ON THE BERKELEY CAMPUS OF THE

UNIVERSITY OF CALIFORNIA

I939

UNIVERSITY OF CALIFORNIA PRESS

BERKELEY AND LOS ANGELES

I94I 


\section{UNIVERSITY OF CALIFORNIA PRESS}

BERKELEY, CALIFORNIA

\section{Cambridge University Press}

LONDON, ENGLAND

COPYRIGHT, 194I, BY

THE REGENTS OF THE UNIVERSITY OF CALIFORNIA

Price: Cloth, \$1.50; Paper, \$1.00

PRINTED IN THE UNITED STATES OF AMERICA BY SAMUEL T. FARQUHAR, UNIVERSITY PRINTER 